\title{
Postoperative Bacterial/Fungal Infections: A Challenging Problem in Critically III Patients after Abdominal Surgery
}

\author{
C. Lichtenstern $^{\mathrm{a}}$ J. Schmidt ${ }^{\mathrm{b}}$ H.P. Knaebel ${ }^{\mathrm{b}}$ E. Martin ${ }^{\mathrm{a}}$ M.W. Büchler ${ }^{\mathrm{b}}$ \\ M.A. Weigand ${ }^{\mathrm{a}}$
}

Departments of a Anesthesiology and ${ }^{\mathrm{b}}$ General Surgery, University of Heidelberg, Heidelberg, Germany

\section{Key Words}

Bacteria $\cdot$ Fungi $\cdot$ Antibacterial treatment $\cdot$ Antifungal treatment

\begin{abstract}
Critically ill patients after extended surgical procedures are at high risk for postoperative infections. The overall incidence of sepsis increased constantly over the last decade, whereas sepsis-related mortality decreased, due to new intensive care options. After extended intra-abdominal surgery the abdomen is the predominant focus of sepsis, followed by respiratory tract infections. Unspecific clinical signs lead to the diagnosis of postoperative sepsis. Early focus identification by clinical, laboratory and radiologic examination is of major importance for a promising therapy, followed by immediately initiated procedures for source control and an adequate anti-infective drug therapy. For nosocomial sepsis, the use of antimicrobial regimens with extended spectra and potent activity against both Gramnegative and Gram-positive bacterial pathogens are warranted. Fungal infections play a great role for immunocompromized patients, e.g. after solid organ transplantation or under chronic corticoid therapy. An increasing incidence of multi-drug resistance in bacterial and fungal isolates has been observed in the last years. This is becoming a growing problem also for critically ill patients after abdominal surgery. Standardized treatment protocols including support-
\end{abstract}

ive and adjunctive therapy and the use of modern anti-infective agents may lead to a decrease in postoperative mortality due to sepsis.

Copyright $\odot 2007$ S. Karger AG, Basel

\section{Introduction}

Surgical patients usually show a postoperative acutephase response typically lasting for 48 up to $96 \mathrm{~h}$ after the surgical procedure [1]. If the acute-phase response persists for longer than $96 \mathrm{~h}$, or a secondary occurrence of symptoms after the primary resolution takes place, an infection is likely to be the reason. Systemic inflammatory response syndrome (SIRS) caused by infection is defined as sepsis.

\section{Epidemiology}

Martin et al. [2] demonstrated in their review of discharge data of about 750 million hospitalizations in the United States in the 22-year period from 1979 to 2000 that the incidence of sepsis in general increased over the observation period. The incidence of sepsis increased by $8.7 \%$ per year from 164,000 (82.7/100,000 population) in 1979 to nearly 660,000 (240.4/100,000 population) in 2000. Whereas sepsis-associated mortality declined from 


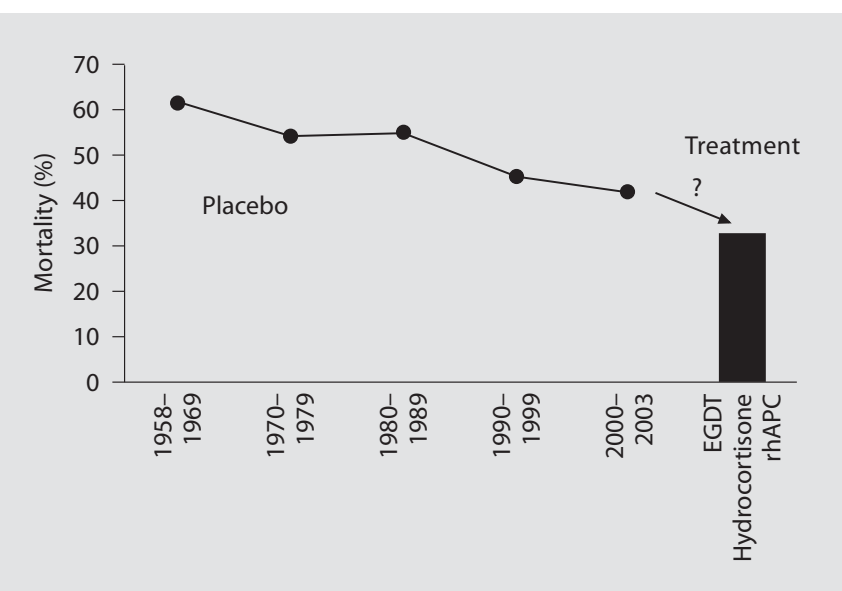

Fig. 1. Sepsis-related mortality. Data from Friedman et al. [66], Barie et al. [8], Rivers et al. [12] and Annane et al. [67]. EGDT = Early goal directed therapy; $\mathrm{rhAPC}=$ recombinant human activated protein $\mathrm{C}$.

27.8 to $17.9 \%$ in this study, the total number of deaths due to sepsis increased due to the higher incidence [2]. Mortality from septic shock also decreased over time; however, still remaining unacceptably high (fig. 1). On average, over the 22-year period sepsis occurred in $1.3 \%$ of all hospitalizations. The age of patients with sepsis increased (1979-1984: 57.4 years vs. 1995-2000: 60.8 years). The authors discussed the increased use of invasive procedures (including surgery, e.g. more transplantation of solid organs), immunosuppressive drugs, chemotherapy, patients with human immunodeficiency virus (HIV) infection and the emergence of multi-drug resistant bacteria as reasons for the higher sepsis incidence in the last years.

To determine the prevalence of nosocomial infections, the SOAP Study was conducted in 2002 among European intensive care units as a 15-day observation with 3,147 included patients [3]. In this study $37 \%$ of all ICU patients had an identified infection and almost $24 \%$ of them had their infection acquired in the ICU. Pneumonia or other respiratory tract infections (68\%) were the most common infections, followed by abdominal infections (22\%), primary bloodstream infections $(20 \%)$ and urinary tract infections (14\%). The overall hospital mortality of the infected patients was 24\% (ICU mortality: 19\%). In the former EPIC Study [4] which was conducted in 1992 among European intensive care units to determine the prevalence of nosocomial infections seven risk factors for ICUacquired infections were identified (table 1).

Of all septic patients $21.4 \%$ are surgical patients [2, 5, 6]. In recent sepsis studies the intra-abdominal infections
Table 1. Risk factors for ICU-acquired infections

\begin{tabular}{ll}
\hline ICU-acquired infections & Death \\
\hline Pulmonary artery catheterization & Age $>60$ years \\
Central venous line & Organ failure on admission \\
Stress ulcer prophylaxis & APACHE II score $>30$ \\
Urinary catheterization & ICU stay $>20$ days \\
Mechanical ventilation & Pneumonia \\
Trauma on admission & Clinical sepsis \\
Length of ICU stay & Laboratory proven bacteremia \\
& Cancer \\
\hline
\end{tabular}

Adapted from Vincent et al. [4].

appear to be the source of sepsis in about $20-38 \%$ [7]. If only surgical patients were considered, the rate of the abdomen as the sepsis focus would be considerably higher. The PROWESS Study showed that intra-abdominal infections are the source of sepsis in septic patients after general surgery in $85 \%$ [8].

Common causes of intra-abdominal infections (IAI) in patients in intensive care units are perforations of the upper gastrointestinal tract secondary to ulcer disease or of the lower gastrointestinal tract secondary to diverticular disease or cancer. Gut ischemia due to arterial embolism, thrombosis or arterial vascular disease as a cause of peritonitis is predominantly seen in elderly patients. Super-infection of the abdominal cavity commonly complicates the course of severe necrotizing pancreatitis or chronic liver failure. After previous abdominal surgery, an anastomotic leakage, an intra-abdominal abscess, or inadvertent and undetected injury of the bowel could be the reason of further abdominal sepsis [1]. Thus, the pancreatic fistula has been regarded as the most frequent major complication after pancreaticoduodenectomy, which ranges from $2 \%$ to over $20 \%$ [9].

Long-term quality of life in survivors is comparatively good, so that all efforts are justified for therapy of postoperative bacterial or fungal infections [1].

\section{Diagnosis of Postoperative Bacterial/Fungal Infections}

The diagnosis of postoperative infections is difficult because clinical signs (pain, changes in level of consciousness, etc.) and laboratory findings like elevated acutephase reactants (e.g. CRP) or fevers are unspecific and could be based only on the extended surgical procedure 


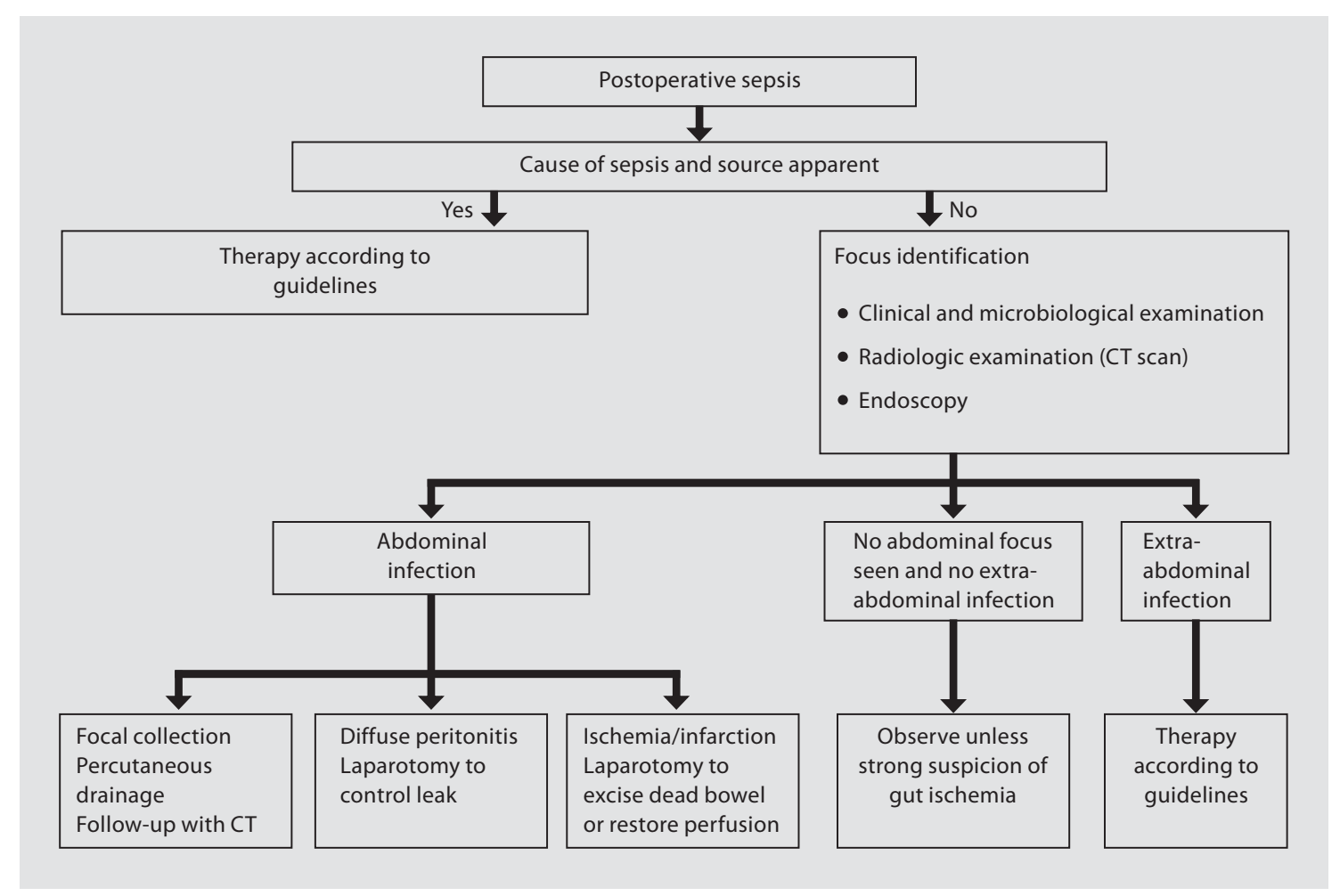

Fig. 2. Diagnostic management of postoperative sepsis. Modified from Marshall et al. [1].

(table 2). Even organ dysfunctions are described related to postoperative SIRS without proven infection. However, persisting (over $72 \mathrm{~h}$ after surgical procedure) elevated response parameters or their secondary rise indicate postoperative sepsis. Newer laboratory parameters with shorter plasma half-life like procalcitonin could turn out to be advantageous over routine parameters like leukocyte counts or CRP in the postoperative monitoring.

The diagnosis of a postoperative peritonitis is particularly difficult. It is primarily based upon clinical signs (table 2). In case of abnormal clinical manifestations in the postoperative period an IAI must be ruled out. Radiographic examinations, especially computer tomography (CT) and ultrasonography, permit the evaluation of intra-abdominal septic foci and constitute the gold-standard for diagnosis of postoperative intra-abdominal infections [10]. Close-meshed reevaluations of the diagnostic results serve for an adequate management and set the right time for re-operation (fig. 2, 3; table 4).

In surgical patients with a septic syndrome, showing no response to a broad-spectrum antibiotic therapy, a disseminated fungal infection must be taken into consideration [11]. Positive blood cultures confirm the diag-
Table 2. Clinical manifestations of postoperative intra-abdominal infections

\section{Response parameters \\ Fever (core temperature $>38.3^{\circ} \mathrm{C}$ ) \\ Leukocytosis (WBC count $>12,000$ cells $/ \mathrm{mm}^{3}$ ) \\ Leukopenia (WBC count $<4,000$ cells $/ \mathrm{mm}^{3}$ ) \\ Plasma C-reactive protein $>2$ SD above normal value \\ Plasma procalcitonin $>2$ SD above normal value}

\section{Organ dysfunction}

Cerebral confusion/delirium

Unanticipated shortness of breath

New onset of supraventricular dysrhythmia

New onset of renal dysfunction

Positive fluid balance/fluid retention

Elevation of bilirubin or transaminase levels

Adapted from Marshall et al. [1].

nosis of a fungal sepsis; however, their sensitivity is just $70 \%$. Intra-operative samples, percutaneous punctures, drainage fluids and urine cultures could lead to the diagnosis of fungal infection, but do not really prove the 
Fig. 3. Model of a standardized treatment protocol for sepsis therapy.

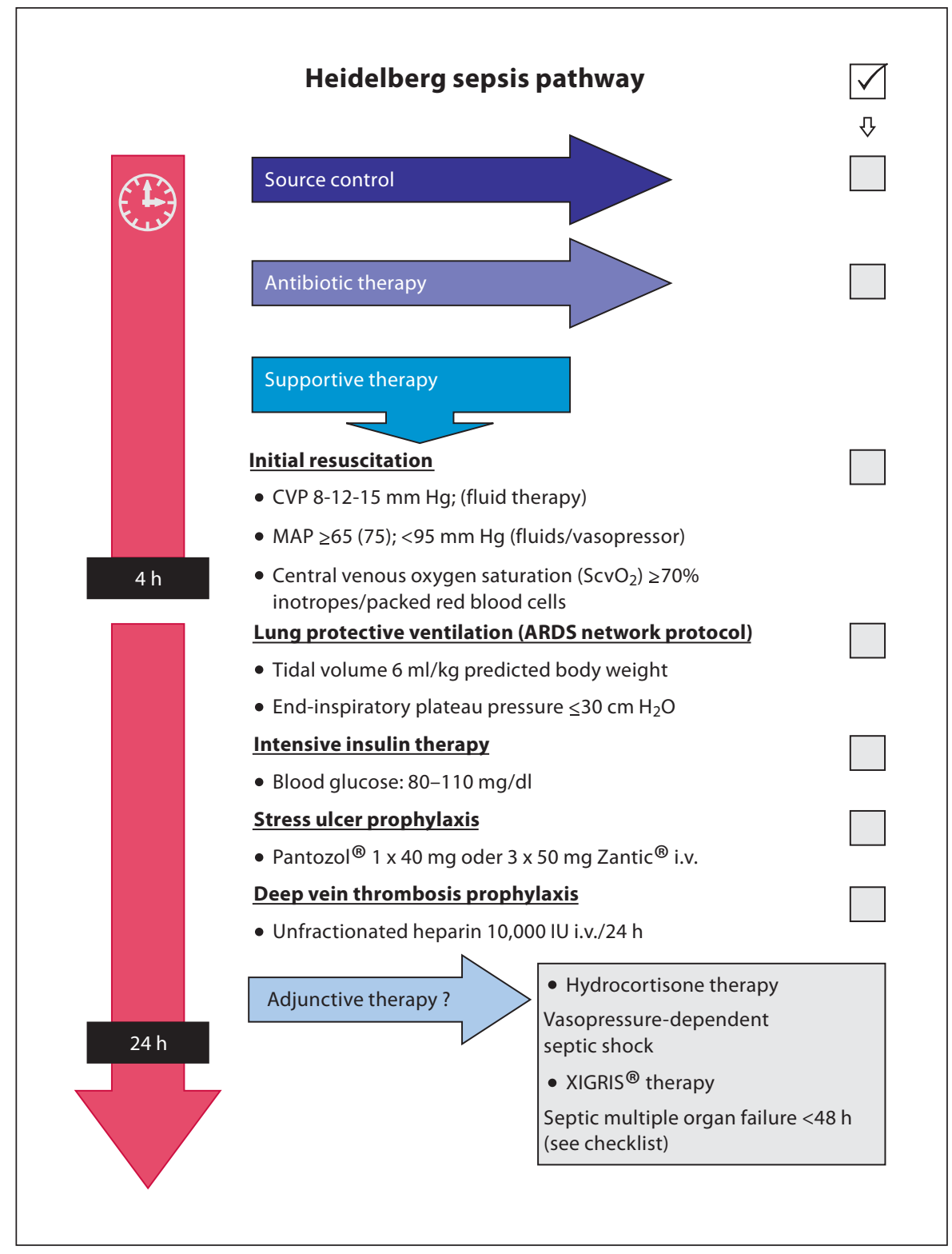

infection. Only histologically proven invasive fungal growth in a biopsy of sterile tissues confirms the diagnosis.

\section{Therapy of Postoperative Bacterial/Fungal Infections}

The therapy of postoperative bacterial/fungal infections consists of source control, antimicrobial therapy, supportive and adjunctive strategies.
Source Control

Marshall et al. [10] lists the three cardinal principles of source control: (1) drainage of infected fluid collections; (2) debridement of infected solid tissue and removal of devices or foreign bodies, and (3) definitive measures to correct anatomic derangements resulting in ongoing microbial contamination and to restore optimal function.

\section{Pathogens and Strategies of Antimicrobial Therapy}

Many strategies are discussed in recent studies to reduce the actually inadequate high mortality of sepsis. Re- 
cent studies underline that time from the beginning of infection to administration of antibiotics is a critical factor to reduce mortality in sepsis treatment. For example the early goal-directed therapy described by Rivers et al. [12] reduces sepsis mortality by $15 \%$. Inadequate and delayed antibiotic therapy increases the mortality in critically ill patients [13-18]. Recently, Kumar et al. [19] showed that survival of septic shock is decreased by 5 $10 \%$ for each additional hour of delay in antibiotic treatment. Best results are obtained when adequate antibiotics are given within the first half hour after the occurrence of hypotension. An adequate antimicrobial regimen is the main requirement in sepsis therapy and leads to reduced lethality [20]. An ideal antimicrobial agent for sepsis therapy should cover the sepsis-inducing pathogens, minimize development of resistant bacterial or fungal strains, and is available at reasonable costs. For nosocomial infections, including intra-abdominal infections, the use of antimicrobial regimens with extended spectra may be warranted.

Bacterial or fungal intra-abdominal infections in critically ill patients are mostly acquired as complications of previous elective or emergency surgery. These infections are caused by a wide spectrum of pathogens, which are dependent on the site of operation and on specific hospital and ICU conditions [21].

Martin et al. [2] reported that, until 1987, Gram-negative bacteria were the predominant pathogens causing sepsis. In the following years Gram-positive organisms have emerged as the leading pathogens. Gram-positive bacteria are found most frequently in cardiovascular and bloodstream infections [22]. An increasing incidence of multi-drug resistance in these isolates is observed in the last years, thus it became a growing problem for all surgical patients. New resistance problems can emerge via species selection, mutation, or DNA transfer. Drug-resistant pathogens are especially prevalent in ICUs with intensive antibiotic usage [23]. Methicillin-resistant Staphylococcus aureus (MRSA), vancomycin-resistant Enterococci (VRE), extended spectrum $\beta$-lactamase-producing bacteria (ESBL), multi-drug resistance in Mycobacterium tuberculosis (MDRTB) strains as well as multi-drug resistant Gram-negative bacteria are seen in postoperative surgical patients. Although the data are conflicting, some clues hint at a higher infection-related mortality associated with these resistant organisms [24-28].

Additionally, in the past two decades fungal infections have become increasingly apparent in critically ill patients. Yeasts like Candida spp. are the predominant fungal pathogens in intensive care units (ICUs) both in Eu- rope and the United States, with reported rates ranging from 2.1 to 20.0 per 1,000 admissions. In non-neutropenic surgical patients, the majority of fungal nosocomial pathogens are Candida spp. [29]. Candida albicans accounts for about $60 \%$ and important additional Candida species include Candida krusei and Candida glabrata. The number of these non-albicans candidemia increased constantly to about $40 \%$, which is called a 'shifting epidemiology'. C. krusei is primarily resistant against fluconazole and C. glabrata frequently develops resistance to fluconazole and itraconazole [30]. Some authors have attributed this emergence of non-albicans species to the use of fluconazole, whereas other reports have failed to find a clear epidemiological association [30]. Antifungal prophylaxis has been proven effective in certain high-risk patients, such as bone marrow transplant and liver transplant patients [31]. Due to the lack of reliable diagnostic tests and limited therapeutic options, fungal infections are associated with a high overall mortality (35-80\%) [32]. Mortality attributable to Candida infection is determined at $4.4-7.2 \%$ [33]. The major risk factors for invasive fungal infections are colonization with Candida of $\geq$ two sites, previous broad-spectrum antibiotic therapy, gastrointestinal surgery or gastrointestinal perforation, acute renal and liver failure, invasive devices such as central venous catheters, immuno-suppression, parenteral nutrition, high APACHE II score, and length of ICU stay (LOS) [30]. In the NEMIS study, most cases of candidemia (76\%) occurred within the first 3 weeks of admission to a surgical ICU. Molds, like Aspergillus spp., are of particular interest for immunocompromised patients. The currently growing number of patients under systemic corticoid therapy for internal diseases, or under immunosuppression after solid-organ transplantation paves the way for a significant rise of these fungal infections in surgical ICUs. Nevertheless, also patients without drugs for immunosuppression can acquire Aspergillus infections, especially following severe peritonitis.

\section{Antibacterials}

Currently, established empiric antibiotic strategies for patients with sepsis due to postoperative abdominal infections include single- and multiple-agent regimens [21,3436]. Recommended regimens for therapy of nosocominal sepsis without knowledge of the presumable pathogen are carbapenems (imipenem/cilastatin or meropenem) and piperacillin plus tazobactam. Furthermore, established alternatives are third- and fourth-generation cephalosporins (ceftazidime or cefepime), fluorochinolones (ciprofloxacin or levofoxacin) and azetreonam, which have to 
be combined with metronidazole to cover anaerobic bacteria. However, resistance rate of Escherichia coli to chinolones is rising up to more than $30 \%$ worldwide limiting its use in empirical therapy. Whether the combination of carbapenems or piperacillin/tazobactam with a chinolone or an aminoglycoside might be favorable in high-risk ICU patients, e.g. after extended surgery or in patients who are mechanically ventilated, has still to be determined in randomized trials. In hospitals with high MRSA rates and after positive culture results a combined therapy with linezolid or with a glycopeptide like vancomycin, or tigecycline is recommended. For patients with severe intra-abdominal infections without severe sepsis, cefotaxim and ceftriaxone combined with metronidazole or moxifloxacin, ertapenem [37] or tigecycline [38] can be used as monotherapeutics.

The routine coverage of isolated Enterococci in patients with community-acquired IAI is not necessary, because in many prospective trials no survival advantage has been shown [21]. But antimicrobial therapy for Enterococci should be given when Enterococci are recovered from patients with health care-associated infections [21]. Therefore, carbapenems and piperacillin/tazobactam possess adequate activity against Enterococcus faecalis with a lower rate of adverse effects than vancomycin. For Entereococcus faecium only linezolid and tigecycline have reliable effectiveness, whereas carbapenems, piperacillin/tazobactam and vancomycin are only intermediary active. Vancomycin-resistant E. faecium isolates (VRE) constitute a further emerging problem of multi-drug resistant pathogens. Cephalosporines plus chinolones have only restricted activity against Enterococci. Furthermore, a relevant rate of nosocomial sepsis is caused by $P$. aeruginosa. Thus, for severe sepsis the antibiotic regimen must include a strong activity against Pseudomonas [21].

For multi-drug resistant bacteria the therapeutic options are limited to only a few modern antibacterials. In infections with MRSA, linezolid showed significantly higher survival and clinical cure rates than vancomycin in recently published studies [39-41].

Tigecycline is the first available agent of a new class of broad-spectrum antibacterials called glycylcyclines [38, 42]. It is effective in the treatment of intra-abdominal infections, and in skin/skin-structure infections. Glycylcyclines are bacteriostatically active by blocking the protein synthesis after binding to the bacterial ribosome. Tigecycline has shown activity against Gram-negative and Gram-positive pathogens including multi-drug resistant Staphylococci, Enterococci or Streptococci as well as most Enterobacteriaceae, anaerobic organisms and Acineto- bacter baumannii [43]. Thus, it can serve for reserve therapy of nosocomial sepsis caused by multi-drug resistant bacterial strains. However, a decreased susceptibility to tigecycline is seen in Proteeae like Morganella morganii and Pseudomonas spp. [44]. For multi-drug resistant Pseudomonas infections, intravenous colistin is used again [45].

Another new class of antibiotics, the cyclic lipopeptide with their first licensed agent daptomycin, is active against a wide range of Gram-positive and anaerobic pathogens including the multi-drug resistant strains, but not against Gram-negative bacteria. For the treatment of Gram-positive skin infections daptomycin showed an equal safety and efficacy compared to conventional therapy with penicillinase-resistant penicillins or vancomycin [46]. In addition, daptomycin is effective in the treatment of bacteremia and right-sided endocarditis caused by $S$. aureus [47]. It is not suitable for treatment of pneumonia, because the drug is inactivated by surfactant.

\section{Therapeutic Strategies in Case of Fungal Infections}

New therapeutic options like modern triazole derivates (e.g. voriconazole) and the new echinocandin agents (e.g. caspofungin) or lipid formulations of amphotericin $B$ reveal new chances in the antifungal treatment of surgical ICU patients (table 3). For treatment, there are two main questions: (1) when should antifungal therapy be applied, and (2) which agent is appropriate?

Some publications recommend a prophylactic application of antifungal agents to reduce infection rates of patients at risk without any symptoms of a fungal infection. In most clinical trials fluconazole served for antimycotic prophylaxis. It has been proven effective against Candida mycoses in certain high-risk patients, such as bone marrow transplant and liver transplant patients [31]. Shorr et al. [48] published a meta-analysis for fluconazole prophylaxis in critically ill surgical patients, which showed that prophylactic fluconazole therapy might decrease the rate of fungal infections, but this strategy did not improve survival of surgical ICU patients [48, 49]. Because of the absence of a survival advantage, routine fluconazole prophylaxis in surgical ICU patients has to be evaluated in consideration of drug side effects, costs, and the potential for development of resistance [50] and the selection of non-albicans isolates. Currently, it is unclear whether prophylactic antifungal treatment has beneficial effects when broadly used in surgical ICUs.

However, the high morbidity and mortality of disseminated fungal infections requires an early therapeutic initiation at a time when further complications still can be 
Table 3. Susceptibility of fungal pathogens

\begin{tabular}{|c|c|c|c|c|c|c|c|c|c|}
\hline \multirow[t]{2}{*}{ Fungal pathogen } & \multicolumn{9}{|c|}{ Antimycotic substances } \\
\hline & $\begin{array}{l}\text { flucon- } \\
\text { azole }\end{array}$ & $\begin{array}{l}\text { itracon- } \\
\text { azole }\end{array}$ & $\begin{array}{l}\text { voricon- } \\
\text { azole }\end{array}$ & $\begin{array}{l}\text { posacon- } \\
\text { azole }\end{array}$ & $\begin{array}{l}\text { caspo- } \\
\text { fungin }\end{array}$ & $\begin{array}{l}\text { mica- } \\
\text { fungin }\end{array}$ & $\begin{array}{l}\text { anidula- } \\
\text { fungin }\end{array}$ & $\begin{array}{l}\text { flucy- } \\
\text { tosin }\end{array}$ & $\begin{array}{l}\text { ampho- } \\
\text { tericin } \mathrm{B}\end{array}$ \\
\hline \multicolumn{10}{|l|}{ Yeast fungus } \\
\hline C. albicans & $\mathrm{S}$ & $\mathrm{S}$ & $\mathrm{S}$ & $\mathrm{S}$ & $\mathrm{S}$ & $\mathrm{S}$ & $\mathrm{S}$ & $\mathrm{S}$ & $S$ \\
\hline C. glabrata & $\mathrm{I}-\mathrm{R}$ & $\mathrm{R}$ & I & $\mathrm{I}$ & S & $\mathrm{S}$ & $\mathrm{S}$ & $\mathrm{S}$ & I \\
\hline C. parapsilosis & $\mathrm{S}$ & $\mathrm{I}$ & $\mathrm{S}$ & $\mathrm{S}$ & $\mathrm{I}$ & $?$ & $?$ & $\mathrm{~S}$ & S \\
\hline C. tropicalis & S & I & $\mathrm{S}$ & $\mathrm{S}$ & S & $\mathrm{S}$ & S & $\mathrm{S}$ & $S$ \\
\hline C. krusei & $\mathrm{R}$ & $\mathrm{R}$ & $\mathrm{I}$ & $\mathrm{I}$ & $\mathrm{S}$ & $\mathrm{S}$ & $\mathrm{S}$ & $\mathrm{I}-\mathrm{R}$ & I \\
\hline C. lusitaniae & $\mathrm{S}$ & $\mathrm{S}$ & $\mathrm{S}$ & $\mathrm{S}$ & $\mathrm{S}$ & $\mathrm{S}$ & $\mathrm{S}$ & $\mathrm{S}$ & $\mathrm{R}$ \\
\hline Cryptococcus & $\mathrm{S}$ & $\mathrm{S}$ & $\mathrm{S}$ & $\mathrm{S}$ & $\mathrm{R}$ & $\mathrm{R}$ & $\mathrm{R}$ & $\mathrm{S}$ & $\mathrm{S}$ \\
\hline \multicolumn{10}{|l|}{ Mould fungus } \\
\hline A. fumigatus & $\mathrm{R}$ & $\mathrm{S}$ & S & $\mathrm{S}$ & S & $\mathrm{S}$ & S & $\mathrm{R}$ & S \\
\hline A. flavus & $\mathrm{R}$ & $\mathrm{S}$ & $\mathrm{S}$ & $\mathrm{S}$ & $\mathrm{S}$ & $\mathrm{S}$ & $\mathrm{S}$ & $\mathrm{R}$ & I-R \\
\hline A. niger & $\mathrm{R}$ & $\mathrm{I}$ & S & S & $\mathrm{S}$ & S & S & $\mathrm{R}$ & S \\
\hline A. terreus & $\mathrm{R}$ & $\mathrm{S}$ & $\mathrm{S}$ & $\mathrm{S}$ & $\mathrm{S}$ & $\mathrm{S}$ & $\mathrm{S}$ & $\mathrm{R}$ & $\mathrm{R}$ \\
\hline Mucor spp. & $\mathrm{R}$ & $\mathrm{R}$ & $\mathrm{R}$ & $\mathrm{S}$ & $\mathrm{R}$ & $\mathrm{R}$ & $\mathrm{R}$ & $\mathrm{R}$ & S \\
\hline Rhizopus spp. & $\mathrm{R}$ & $\mathrm{R}$ & $\mathrm{R}$ & $\mathrm{S}$ & $\mathrm{R}$ & $\mathrm{R}$ & $\mathrm{R}$ & $\mathrm{R}$ & S \\
\hline Fusarium spp. & $\mathrm{R}$ & $\mathrm{R}$ & $\mathrm{S}$ & S & $\mathrm{R}$ & $\mathrm{R}$ & $\mathrm{R}$ & $\mathrm{R}$ & I \\
\hline
\end{tabular}

$\mathrm{S}=$ Susceptible; $\mathrm{I}=$ intermediately resistant; $\mathrm{R}=$ resistant.

reduced [51]. But inadequate diagnostic opportunities make the indication for antifungal therapy difficult. Widespread use of inappropriate antimycotic therapy may have deleterious epidemiological consequences, including selection of resistant organisms. In the guidelines for treatment of candidiasis [52] an empirical therapy is recommended to patients with (1) Candida species colonization (preferably at multiple sites [53]; (2) multiple other risk factors like prolonged use of antibiotics, presence of central venous catheters, hyperalimentation, surgery (especially surgery that transects the gut wall), and prolonged ICU stay, and (3) absence of any other uncorrected causes of fever. However, colonization of at least two sterile sites alone usually should not be treated because a reduction in mortality is not seen until now. Even the recovery of Candida species from urine samples are not associated with a significant increase of subsequent candidemia [30]. The absence of colonization by Candida species indicates a lower risk for invasive candidiasis and warrants a delaying empirical therapy.

As treatment options amphotericin B and for a limited spectrum of Candida species fluconazole are mentioned in the guidelines [52]. The various studies published regarding currently available alternative antifungal drugs have been performed for the empirical therapy of persistent fever in patients with neutropenia. Caspofungin [54]
Table 4. Diagnostic applications for focus identification

Clinical examination

Microbiological examination of: bronchioalveolar lavage, blood culture, urine culture, intraoperative/wound swabs, drainage fluids

X-ray: thorax, abdomen, paranasal sinuses

Ultrasonography (including interventional drainage)

Computertomography (CT) with i.v./oral/rectal water-soluble contrast media (including interventional drainage)

Radionuclide scan

Fistulography

Endoscopy: esophagogastroscopy, rectosigmoidocoloscopy

Oral administration of methylene blue solution

and voriconazole [55] were as effective as liposomal amphotericin B with fewer therapy related adverse side effects and a tendency to lower rates of breakthrough infections. For the empirical antimycotic treatment of surgical patients caspofungin and voriconazole both appear to be suitable, and perhaps preferable, alternatives to conventional and liposomal amphotericin B. The important issue now facing clinicians is to determine which patients are most likely to benefit from empirical antifungal therapy [56]. So far, empiric antifungal therapy is not part of the treatment of non-neutropenic septic patients [21]. If 
empirical therapy is started with a modern broad-spectrum antifungal agent, and the fungal pathogen will be verified as sensitive to a narrower spectrum antimycotic agent, the therapy regimens could be deescalated, e.g. to fluconazole for $C$. albicans. The limited data which are available for prophylactic and empirical treatment strategies of invasive fungal infections in solid organ transplant patients have been reviewed very recently by Marik [57].

\section{Candidiasis}

Guideline therapy of candidemia in non-neutropenic patients [52] is amphotercin B, or fluconazole, or caspofungin. Spellberg et al. [58] recently published current treatment strategies including voriconazole as the firstline treatment option. Caspofungin was at least as effective, and less toxic, as amphotericin B for the treatment of candidemia in the randomized, double-blind study of Mora-Duarte et al. [33]. In addition, voriconazole is promising as a salvage agent for the treatment of invasive candidiasis, even in the setting of previous azole therapy [11], and was as effective as amphotericin B followed by fluconazole in the primary therapy of invasive candidiasis [52]. Thus, both seem to be favorable alternatives for critically ill patients. As combination therapy amphotercin B plus fluconazole for 4-7 days, followed by single use of fluconazole [52] could be a further alternative, but drug toxicity of amphotericin B has to be taken in account. Intravascular catheters should be removed or changed because candidiasis is often catheter-related [52].

Primary Candida pneumonia is very rare in non-neutropenic patients. Most commonly, a hematogenous dissemination, rather than primary invasion, is the reason for pulmonary lesions. Candida pneumonia requires histopathological confirmation because benign colonization of the airway with Candida species and contamination of the respiratory secretions with oropharyngeal material is much more common than invasive candidiasis. Nevertheless, when a patient does not respond to antibiotics and Candida is the predominant or sole pathogen in bronchial lavage, therapy has to be given.

For surgical ICU patients Candida peritonitis may develop in association with recurrent gastrointestinal perforations or anastomotic leakage after surgical intervention. Candida species are isolated in $20 \%$ of all patients with peritonitis. If these patients are improving under antibiotics, there is no need for antifungal treatment. However, patients who received chemotherapy for neoplasm or immunosuppressive therapy for transplantation or other in- flammatory diseases are at high risk and have to be treated [14]. Candida species are isolated in intra-operative samples, percutaneous punctures, and drainage fluids as part of a complex polymicrobiological infection [59]. If these patients are not improving despite broad-spectrum antibiotics, antifungal therapy must take place after surgical repair and drainage (i.e. focus control) [21].

\section{Aspergillosis}

Amphotericin B has been the standard therapy for invasive aspergillosis, although the response rate of less than $40 \%$ is suboptimal [60]. In addition, amphotericin B is associated with multiple adverse side effects, which are mentioned above. Furthermore, diagnosis of invasive aspergillosis is very difficult and delayed diagnosis contributes to the inadequate high mortality of more than $50 \%$. Thus, even if the diagnosis is not proven, therapy against Aspergillus species is often initiated empirically. Voriconazole [61] and caspofungin [62] were as effective as amphotericin B in salvage therapy of refractory invasive aspergillosis. However, we have to mention that caspofungin is not effective against other molds which are an emerging problem for patients after bone marrow or solid organ transplantation. In a comparative study for primary therapy of invasive aspergillosis, proven or empirically, voriconazole showed better response rates and an improved survival in neutropenic patients, accompanied with fewer severe side effects than the standard therapy with amphotericin B [63]. Because of its excellent cerebral penetration and fungicidal activity, voriconazole may be the best choice for treatment of cerebral aspergillosis [37]. Because of the high mortality of invasive aspergillosis infections, combination therapies of voriconazole plus caspofungin, voriconazole and liposomal amphotericin B, or caspofungin and liposomal amphotericin B seem to be attractive. Singh et al. [64] recently published data from a prospective multicenter study of voriconazole and caspofungin versus a lipid formulation of amphotericin B as primary therapy for proven or probable invasive aspergillosis in solid organ transplant recipients. In case of renal failure or for infection with Aspergillus fumigatus, combination therapy showed a significantly increased survival at 90 days.

\section{Duration of Antimicrobial Therapy}

Only few data are available to determine the right duration of antibiotic therapy of nosocomial infections. In patients with ventilator-associated pneumonia (VAP) Chastre et al. [65] showed no difference in mortality, recurrent infections, ventilation- and organ failure-free days and length of stay between 8 vs. 15 days duration of 
therapy. But there were more antibiotic-free days in the 8-day course group, indicating a lower risk of drug toxicity and of drug resistance induction. Although patients with VAP caused by non-fermenting Gram-negative bacilli, including P. aeruginosa and Acinetobacter, did not have more unfavorable outcomes when antimicrobial therapy lasted only 8 days, they did have a higher pulmonary recurrence rate compared with those receiving 15 days of treatment (40.6 vs. 25.4\%). Therefore, Marshall et al. [1] concluded for the duration of antibiotic therapy in their ICU that the antibiotic course can be restricted to 5-7 days when source control is adequate. Antibiotics should also be stopped at a maximum of 3-5 days after clinical improvement and remission of organ failure. $P$. aeruginosa and other non-fermenters such as Acinetobacter infections are usually treated for 10-14 days. In patients with abscesses or empyemas, duration of therapy is dependent on the local findings. Catheter-related bloodstream infections with S. aureus are treated for 1014 days. In these cases echocardiography is required to exclude a fluoride endocarditis. Antifungal therapy is usually provided for 14 days after the last positive blood culture. A longer course (4-6 weeks) of antibiotics is given, e.g., in patients with endocarditis and osteomyelitis.
If the infection symptoms are not resolving under antibacterial therapy, sepsis source control has to be reevaluated. Secondary, atypical (including fungi) or multidrug resistant pathogens (e.g. ESBL, MRSA, VRE) could be the cause of sepsis. Pseudomembraneous colitis or drug fever are other reasons of infection-like symptoms, which have to be taken into consideration.

\section{Conclusion}

Postoperative bacterial and fungal infections are a rising problem in critically ill patients after hepato-pancreato-biliary surgery. The decisive factors for a favorable outcome of infected patients are early diagnosis, competent source control, as well as a prompt and adequate antiinfective therapy. Only high potent broad-spectrum antiinfective agents are suitable for the empirical treatment of septic critically ill patients after hepato-pancreato-biliary surgery, accompanied by supportive and adjunctive therapeutic strategies. The increasing prevalence of multi-drug resistant bacterial and fungal isolates must be taken into account, especially in cases of nosocomial sepsis after extended surgical procedures.

\section{References}

1 Marshall JC, Innes M: Intensive care unit management of intra-abdominal infection. Crit Care Med 2003;31:2228-2237.

-2 Martin GS, Mannino DM, Eaton S, Moss M: The epidemiology of sepsis in the United States from 1979 through 2000. N Engl J Med 2003;348:1546-1554.

-3 Vincent JL, Sakr Y, Sprung CL, Ranieri VM, Reinhart K, Gerlach H, Moreno R, Carlet J, Le Gall JR, Payen D: Sepsis in European intensive care units: results of the SOAP study. Crit Care Med 2006;34:344-353.

4 Vincent JL, Bihari DJ, Suter PM, Bruining HA, White J, Nicolas-Chanoin MH, Wolff M, Spencer RC, Hemmer M: The prevalence of nosocomial infection in intensive care units in Europe. Results of the European Prevalence of Infection in Intensive Care (EPIC) Study. EPIC International Advisory Committee. JAMA 1995;274:639-644.

$\checkmark 5$ Angus DC, Linde-Zwirble WT, Lidicker J, Clermont G, Carcillo J, Pinsky MR: Epidemiology of severe sepsis in the United States: analysis of incidence, outcome, and associated costs of care. Crit Care Med 2001;29: 1303-1310.
6 Angus DC, Wax RS: Epidemiology of sepsis: an update. Crit Care Med 2001;29:S109S116.

7 Knaebel HP, Seiler CM, Weigand MA, Büchler MW: Chirurgische Therapie der Peritonitis. Intensivmed up2date 2005; 1: 165-175.

-8 Barie PS WM, McCollam JS, Bates BM, Qualy RL, Lowry SF, Fry DE; PROWESS Surgical Evaluation Committee: Benefit/risk profile of drotrecogin alfa (activated) in surgical patients with severe sepsis. Am J Surg 2004; 188:212-220.

-9 Bassi C, Dervenis C, Butturini G, Fingerhut A, Yeo C, Izbicki J, Neoptolemos J, Sarr M, Traverso W, Buchler M: Postoperative pancreatic fistula: an international study group (ISGPF) definition. Surgery 2005;138:8-13.

10 Marshall JC, Maier RV, Jimenez M, Dellinger EP: Source control in the management of severe sepsis and septic shock: an evidencebased review. Crit Care Med 2004;32:S513S526.

11 Ostrosky-Zeichner L, Pappas PG: Invasive candidiasis in the intensive care unit. Crit Care Med 2006;34:857-863.
12 Rivers E, Nguyen B, Havstad S, Ressler J, Muzzin A, Knoblich B, Peterson E, Tomlanovich M: Early goal-directed therapy in the treatment of severe sepsis and septic shock. N Engl J Med 2001;345:1368-1377.

$>13$ MacArthur RD, Miller M, Albertson T, Panacek E, Johnson D, Teoh L, Barchuk W: Adequacy of early empiric antibiotic treatment and survival in severe sepsis: experience from the MONARCS trial. Clin Infect Dis 2004;38:284-288.

14 Iregui M, Ward S, Sherman G, Fraser VJ, Kollef MH: Clinical importance of delays in the initiation of appropriate antibiotic treatment for ventilator-associated pneumonia. Chest 2002;122:262-268.

$>15$ Clec'h C, Ferriere F, Karoubi P, Fosse JP, Cupa M, Hoang P, Cohen Y: Diagnostic and prognostic value of procalcitonin in patients with septic shock. Crit Care Med 2004;32: 1166-1169.

16 Garnacho-Montero J, Garcia-Garmendia JL, Barrero-Almodovar A, Jimenez-Jimenez FJ, Perez-Paredes C, Ortiz-Leyba C: Impact of adequate empirical antibiotic therapy on the outcome of patients admitted to the intensive care unit with sepsis. Crit Care Med 2003;31:2742-2751. 
17 Ibrahim EH, Sherman G, Ward S, Fraser VJ, Kollef MH: The influence of inadequate antimicrobial treatment of bloodstream infections on patient outcomes in the ICU setting. Chest 2000;118:146-155.

-18 Kollef MH, Sherman G, Ward S, Fraser VJ: Inadequate antimicrobial treatment of infections: a risk factor for hospital mortality among critically ill patients. Chest 1999;115: 462-474.

-19 Kumar A, Roberts D, Wood KE, Light B, Parrillo JE, Sharma S, Suppes R, Feinstein D, Zanotti S, Taiberg L, Gurka D, Kumar A, Cheang M: Duration of hypotension before initiation of effective antimicrobial therapy is the critical determinant of survival in human septic shock. Crit Care Med 2006;34: 1589-1596.

20 Wheeler AP, Bernard GR: Treating patients with severe sepsis. N Engl J Med 1999;340: 207-214.

-21 Solomkin JS, Mazuski JE, Baron EJ, Sawyer RG, Nathens AB, DiPiro JT, Buchman T, Dellinger EP, Jernigan J, Gorbach S, Chow AW, Bartlett J: Guidelines for the selection of anti-infective agents for complicated intraabdominal infections. Clin Infect Dis 2003; 37:997-1005

-22 Solomkin JS, Bjornson HS, Cainzos M, Dellinger EP, Dominioni L, Eidus R, Faist E, Leaper D, Lee JT, Lipsett PA, Napolitano L, Nelson CL, Sawyer RG, Weigelt J, Wilson SE: A consensus statement on empiric therapy for suspected gram-positive infections in surgical patients. Am J Surg 2004;187:134145.

23 Archibald L, Phillips L, Monnet D, McGowan JE Jr, Tenover F, Gaynes R: Antimicrobial resistance in isolates from inpatients and outpatients in the United States: increasing importance of the intensive care unit. Clin Infect Dis 1997;24:211-215.

-24 Linden PK, Pasculle AW, Manez R, Kramer DJ, Fung JJ, Pinna AD, Kusne S: Differences in outcomes for patients with bacteremia due to vancomycin-resistant Enterococcus faecium or vancomycin-susceptible E. faecium. Clin Infect Dis 1996;22:663-670.

25 Edmond MB, Ober JF, Dawson JD, Weinbaum DL, Wenzel RP: Vancomycin-resistant enterococcal bacteremia: natural history and attributable mortality. Clin Infect Dis 1996;23:1234-1239.

-26 Stosor V, Peterson LR, Postelnick M, Noskin GA: Enterococcus faecium bacteremia: does vancomycin resistance make a difference? Arch Intern Med 1998;158:522-527.

27 Krcmery V Jr, Spanik S, Krupova I, Trupl J, Kunova A, Smid M, Pichnova E: Bacteremia due to multiresistant Gram-negative bacilli in neutropenic cancer patients: a case controlled study. J Chemother 1998;10:320325 .

28 Conterno LO, Wey SB, Castelo A: Risk factors for mortality in Staphylococcus aureus bacteremia. Infect Control Hosp Epidemiol 1998;19:32-37.
29 Vincent JL, Anaissie E, Bruining H, Demajo W, el-Ebiary M, Haber J, Hiramatsu Y, Nitenberg G, Nystrom PO, Pittet D, Rogers T, Sandven P, Sganga G, Schaller MD, Solomkin J: Epidemiology, diagnosis and treatment of systemic Candida infection in surgical patients under intensive care. Intens Care Med 1998;24:206-216.

30 Blumberg HM, Jarvis WR, Soucie JM, Edwards JE, Patterson JE, Pfaller MA, RangelFrausto MS, Rinaldi MG, Saiman L, Wiblin RT, Wenzel RP: Risk factors for candidal bloodstream infections in surgical intensive care unit patients: the NEMIS prospective multicenter study. The National Epidemiology of Mycosis Survey. Clin Infect Dis 2001; 33:177-186.

- 31 Goodman JL, Winston DJ, Greenfield RA, Chandrasekar PH, Fox B, Kaizer H, Shadduck RK, Shea TC, Stiff P, Friedman DJ, et al: A controlled trial of fluconazole to prevent fungal infections in patients undergoing bone marrow transplantation. N Engl J Med 1992;326:845-851.

32 Petri MG, Konig J, Moecke HP, Gramm HJ, Barkow H, Kujath P, Dennhart R, Schafer H, Meyer N, Kalmar P, Thulig P, Muller J, Lode $\mathrm{H}$ : Epidemiology of invasive mycosis in ICU patients: a prospective multicenter study in 435 non-neutropenic patients. Paul-Ehrlich Society for Chemotherapy, Divisions of Mycology and Pneumonia Research. Intens Care Med 1997;23:317-325.

33 Mora-Duarte J, Betts R, Rotstein C, Colombo AL, Thompson-Moya L, Smietana J, Lupinacci R, Sable C, Kartsonis N, Perfect J: Comparison of caspofungin and amphotericin B for invasive candidiasis. N Engl J Med 2002;347:2020-2029.

34 Bochud PY, Glauser MP, Calandra T: Antibiotics in sepsis. Intens Care Med 2001;27 (suppl 1):S33-S48.

35 Fagon JY, Chastre J, Wolff M, Gervais C, Parer-Aubas S, Stephan F, Similowski T, Mercat A, Diehl JL, Sollet JP, Tenaillon A: Invasive and noninvasive strategies for management of suspected ventilator-associated pneumonia: a randomized trial. Ann Intern Med 2000;132:621-630.

36 Violan JS, Sanchez-Ramirez C, Mujica AP, Cendrero JC, Fernandez JA, de Castro FR: Impact of nosocomial pneumonia on the outcome of mechanically-ventilated patients. Crit Care (Lond) 1998;2:19-23.

37 DiNubile MJ, Chow JW, Satishchandran V, Polis A, Motyl MR, Abramson MA, Teppler $\mathrm{H}$ : Acquisition of resistant bowel flora during a double-blind randomized clinical trial of ertapenem versus piperacillin-tazobactam therapy for intraabdominal infections. Antimicrob Agents Chemother 2005;49: 3217-3221.
38 Babinchak T, Ellis-Grosse E, Dartois N, Rose GM, Loh E: The efficacy and safety of tigecycline for the treatment of complicated intraabdominal infections: analysis of pooled clinical trial data. Clin Infect Dis 2005; 41(suppl 5):S354-S367.

- 39 Wunderink RG, Rello J, Cammarata SK, Croos-Dabrera RV, Kollef MH: Linezolid vs. vancomycin: analysis of two double-blind studies of patients with methicillin-resistant Staphylococcus aureus nosocomial pneumonia. Chest 2003;124:1789-1797.

40 Weigelt J, Kaafarani HM, Itani KM, Swanson $\mathrm{RN}$ : Linezolid eradicates MRSA better than vancomycin from surgical-site infections. Am J Surg 2004;188:760-766.

41 Weigelt J, Itani K, Stevens D, Lau W, Dryden $\mathrm{M}$, Knirsch C: Linezolid versus vancomycin in treatment of complicated skin and soft tissue infections. Antimicrob Agents Chemother 2005;49:2260-2266.

42 Ellis-Grosse EJ, Babinchak T, Dartois N, Rose G, Loh E: The efficacy and safety of tigecycline in the treatment of skin and skinstructure infections: results of 2 doubleblind phase 3 comparison studies with vancomycin-aztreonam. Clin Infect Dis 2005; 41(suppl 5):S341-S353.

43 Rubinstein E, Vaughan D: Tigecycline: a novel glycylcycline. Drugs 2005;65:13171336.

44 Livermore DM: Tigecycline: what is it, and where should it be used? J Antimicrob Chemother 2005;56:611-614.

-45 Falagas ME, Kasiakou SK: Colistin: the revival of polymyxins for the management of multidrug-resistant gram-negative bacterial infections. Clin Infect Dis 2005;40:13331341.

46 Arbeit RD, Maki D, Tally FP, Campanaro E, Eisenstein BI: The safety and efficacy of daptomycin for the treatment of complicated skin and skin-structure infections. Clin Infect Dis 2004;38:1673-1681.

47 Fowler VG Jr, Boucher HW, Corey GR, Abrutyn E, Karchmer AW, Rupp ME, Levine DP, Chambers HF, Tally FP, Vigliani GA, Cabell CH, Link AS, DeMeyer I, Filler SG, Zervos M, Cook P, Parsonnet J, Bernstein JM, Price CS, Forrest GN, Fatkenheuer G, Gareca M, Rehm SJ, Brodt HR, Tice A, Cosgrove SE: Daptomycin versus standard therapy for bacteremia and endocarditis caused by Staphylococcus aureus. N Engl J Med 2006;355:653-665.

48 Shorr AF, Chung K, Jackson WL, Waterman PE, Kollef MH: Fluconazole prophylaxis in critically ill surgical patients: a meta-analysis. Crit Care Med 2005;33:1928-1935.

49 Pelz RK, Hendrix CW, Swoboda SM, EnerWest M, Merz WG, Hammond J, Lipsett PA: Double-blind placebo-controlled trial of fluconazole to prevent candidal infections in critically ill surgical patients. Ann Surg 2001; 233:542-548. 
50 Magill SS, Shields C, Sears CL, Choti M, Merz WG: Triazole cross-resistance among Candida spp.: case report, occurrence among bloodstream isolates, and implications for antifungal therapy. J Clin Microbiol 2006; 44:529-535.

51 Morrell M, Fraser VJ, Kollef MH: Delaying the empiric treatment of Candida bloodstream infection until positive blood culture results are obtained: a potential risk factor for hospital mortality. Antimicrob Agents Chemother 2005;49:3640-3645.

52 Kullberg BJ, Sobel JD, Ruhnke M, Pappas PG, Viscoli C, Rex JH, Cleary JD, Rubinstein E, Church LW, Brown JM, Schlamm HT, Oborska IT, Hilton F, Hodges MR: Voriconazole versus a regimen of amphotericin $\mathrm{B}$ followed by fluconazole for candidaemia in non-neutropenic patients: a randomised non-inferiority trial. Lancet 2005;366:1435-1442.

53 Harbarth S, Holeckova K, Froidevaux C, Pittet D, Ricou B, Grau GE, Vadas L, Pugin $\mathrm{J}$ : Diagnostic value of procalcitonin, interleukin-6, and interleukin-8 in critically ill patients admitted with suspected sepsis. Am J Respir Crit Care Med 2001;164:396-402.

-54 Walsh TJ, Teppler H, Donowitz GR, Maertens JA, Baden LR, Dmoszynska A, Cornely OA, Bourque MR, Lupinacci RJ, Sable CA, dePauw BE: Caspofungin versus liposomal amphotericin B for empirical antifungal therapy in patients with persistent fever and neutropenia. N Engl J Med 2004;351:1391-1402.

-55 Walsh TJ, Pappas P, Winston DJ, Lazarus HM, Petersen F, Raffalli J, Yanovich S, Stiff P, Greenberg R, Donowitz G, Schuster M, Reboli A, Wingard J, Arndt C, Reinhardt J, Hadley S, Finberg R, Laverdiere M, Perfect J, Garber G, Fioritoni G, Anaissie E, Lee J: Voriconazole compared with liposomal amphotericin B for empirical antifungal therapy in patients with neutropenia and persistent fever. N Engl J Med 2002;346:225-234.
56 Klastersky J: Antifungal therapy in patients with fever and neutropenia - more rational and less empirical? N Engl J Med 2004;351: 1445-1447.

57 Marik PE: Fungal infections in solid organ transplantation. Expert Opin Pharmacother 2006;7:297-305.

58 Spellberg BJ, Filler SG, Edwards JE Jr: Current treatment strategies for disseminated candidiasis. Clin Infect Dis 2006;42:244251.

59 Sandven P, Qvist H, Skovlund E, Giercksky KE: Significance of Candida recovered from intraoperative specimens in patients with intra-abdominal perforations. Crit Care Med 2002;30:541-547.

60 Stevens DA, Kan VL, Judson MA, Morrison VA, Dummer S, Denning DW, Bennett JE, Walsh TJ, Patterson TF, Pankey GA: Practice guidelines for diseases caused by Aspergillus. Infectious Diseases Society of America. Clin Infect Dis 2000;30:696-709.

61 Perfect JR, Marr KA, Walsh TJ, Greenberg RN, DuPont B, de la Torre-Cisneros J, JustNubling G, Schlamm HT, Lutsar I, EspinelIngroff $\mathrm{A}$, Johnson $\mathrm{E}$ : Voriconazole treatment for less-common, emerging, or refractory fungal infections. Clin Infect Dis 2003;36:1122-1131.

62 Maertens J, Raad I, Petrikkos G, Boogaerts M, Selleslag D, Petersen FB, Sable CA, Kartsonis NA, Ngai A, Taylor A, Patterson TF, Denning DW, Walsh TJ: Efficacy and safety of caspofungin for treatment of invasive as pergillosis in patients refractory to or intolerant of conventional antifungal therapy. Clin Infect Dis 2004;39:1563-1571.
63 Herbrecht R, Denning DW, Patterson TF, Bennett JE, Greene RE, Oestmann JW, Kern WV, Marr KA, Ribaud P, Lortholary O, Sylvester R, Rubin RH, Wingard JR, Stark P, Durand C, Caillot D, Thiel E, Chandrasekar PH, Hodges MR, Schlamm HT, Troke PF, de Pauw B: Voriconazole versus amphotericin B for primary therapy of invasive aspergillosis. N Engl J Med 2002;347:408-415.

64 Singh N, Limaye AP, Forrest G, Safdar N, Munoz P, Pursell K, Houston S, Rosso F, Montoya JG, Patton P, Del Busto R, Aguado JM, Fisher RA, Klintmalm GB, Miller R, Wagener MM, Lewis RE, Kontoyiannis DP, Husain S: Combination of voriconazole and caspofungin as primary therapy for invasive aspergillosis in solid organ transplant recipients: a prospective, multicenter, observational study. Transplantation 2006;81:320326.

65 Chastre J, Wolff M, Fagon JY, Chevret S, Thomas F, Wermert D, Clementi E, Gonzalez J, Jusserand D, Asfar P, Perrin D, Fieux F, Aubas S: Comparison of 8 vs. 15 days of antibiotic therapy for ventilator-associated pneumonia in adults: a randomized trial. JAMA 2003;290:2588-2598.

66 Friedman G, Silva E, Vincent JL: Has the mortality of septic shock changed with time. Crit Care Med 1998;26:2078-2086.

67 Annane D, Sebille V, Charpentier C, Bollaert PE, Francois B, Korach JM, Capellier G, Cohen Y, Azoulay E, Troche G, ChaumetRiffaut P, Bellissant E: Effect of treatment with low doses of hydrocortisone and fludrocortisone on mortality in patients with septic shock. Jama 2002;288:862-871. 